\title{
Auto-ignition characteristics of high-reactivity gasoline fuel using a gasoline multi-hole injector
}

\author{
Jianguo Du ${ }^{\mathrm{a}}$, Balaji Mohan ${ }^{\mathrm{a}, *}$, Jaeheon Sim ${ }^{\mathrm{b}}$, Tiegang Fang ${ }^{\mathrm{c}}$, William L \\ Roberts $^{\mathrm{a}}$ \\ ${ }^{a}$ Clean Combustion Research Center, King Abdullah University of Science and \\ Technology, Thuwal, Makkah Province, Saudi Arabia \\ ${ }^{b}$ Fuel Technology Division, R\&DC, Saudi Aramco, Dhahran, Eastern Province, Saudi \\ Arabia \\ ${ }^{c}$ Department of Mechanical and Aerospace Engineering, North Carolina State University, \\ Raleigh, NC 27695, United States
}

\begin{abstract}
Gasoline compression ignition (GCI) engines have proven to be a highly efficient engine technology with reduced emissions. The high efficiency and reduced emissions of GCI engines heavily rely on the stratification of the fuel being injected directly into the cylinder through multi-hole injectors. Therefore, it is critical to understand the fuel stratification and auto-ignition behaviors of the fuels used in GCI engines. Thus, in this work, the autoignition characteristics of high-reactivity and low carbon gasoline fuel (RON 77) were studied in an optically accessible constant volume chamber. A customized high-pressure gasoline multi-hole injector was used. Reactive tests were performed at two different ambient pressures (20 and 30 bar), three different ambient temperatures (800, 900, and 1000K), three different oxygen concentrations (10, 15 and 21\%) and three different injection pressures (100, 300 and 450 bar). The auto-ignition of fuel was achieved with varying ignition
\end{abstract}

\footnotetext{
*Corresponding author: balaji.mohan@kaust.edu.sa
} 
delay based on the experimental conditions tested. It was found that the operating conditions profoundly influences the diffusion and partially-premixed combustion mode. For high ambient pressures, temperatures, oxygen concentrations, injection pressure, and combinations, diffusion combustion mode was observed, and partially premixed combustion mode was observed at lower ambient pressures, temperatures, oxygen concentrations, injection pressures, and their combinations.

Keywords:

ignition delay, diffusion combustion mode, partially-premixed combustion mode, low carbon fuel

\section{Highlights}

4

5

6

7

- Spray auto-ignition of gasoline multi-hole fuel injector was studied.

- Ignition delay times of high-reactivity low carbon gasoline fuel were measured.

- Effects of ambient temperature, pressure, oxygen concentration and injection pressures were investigated.

- Two different modes of combustion were observed.

\section{Introduction}

Gasoline compression ignition (GCI) engines are gaining popularity among the engine community due to its higher thermal efficiency and relatively lower emissions [1, 2]. GCI engines have significant advantages of acheiving both diesel-like high thermal efficiency and gasoline-like low emissions. Typical 
Gasoline with low reactivity and higher octane numbers can be used in GCI engines. However, high-reactivity gasoline-like fuels in the same gasoline boiling range are more desirable for auto-ignition by compression. Many fuels with different physical and chemical properties, such as distillation curves, chemical compositions, and ignition quality, have been considered in the previous works. Some of the fuels considered are conventional gasolines [3, 4], diesel [5], gasoline/diesel blends [6], binary and ternary fuel blends [7] and low-octane gasoline fuels $[8,9,10]$. Kolodziej et al. [11] analyzed GCI engine performance and emissions using fuel ranging from octane numbers of 6091. They found that RON 80 fuel showed promising results in GCI engines. Recently, Jiang et al. [12] studied the effects of exhaust gas recirculation and fuel octane number on the performance and emissions of GCI engines. It was reported that the PRF70 fuel provided the highest indicated thermal efficiency of $47 \%$ under medium load conditions. Therefore, a new fuel was formulated with RON 77 in the objective of developing a fuel with RON 80 and gasoline-like density and boiling characteristics for GCI engine applications. The auto-ignition behavior was studied using shock tube and rapid compression machine for this RON 77 fuel and was reported recently by AlAbbad et al. [13]. This GCI RON 77 fuel is a customized mixture of Saudi Aramco hydrotreated light naphtha (50\% vol.), heavy naphtha (25\% vol.), and a high-octane reformate ( $25 \%$ vol.). The properties of the GCI RON 77 fuel are shown in Table 1.

In compression ignition engines, the combustion completeness depends on the fuel injection process and careful matching of the air-fuel mixture because the fuel stratification and distribution inside the cylinder are governed 
Table 1: Properties of GCI RON 77 fuel [13]

\begin{tabular}{|c|c|}
\hline RON & 77 \\
\hline MON & 73.9 \\
\hline Density $\left(\mathrm{kg} / \mathrm{m}^{3}\right)$ & 720.7 \\
\hline Average MW & 89.97 \\
\hline C $/ \mathrm{H}$ & 5.93 \\
\hline Paraffins ( $\%$ mol.) & 22.4 \\
\hline iso-paraffins (\% mol.) & 41.2 \\
\hline Naphthenes (\% mol.) & 15.6 \\
\hline Aromatics (\% mol.) & 20 \\
\hline
\end{tabular}

by the spray characteristics and atomization [14]. Raman et al.[15] studied the combustion stratification of naphtha fuel in partially premixed combustion (PPC) mode using optical engines and found that the start of injection and dilution of intake affects the fuel-air mixture and emissions such as $\mathrm{NO}_{\mathrm{x}}$ and soot formation. Goyal and Kook [16] studied the ignition process of GCI combustion in a small-bore optical engine and found that the ignition process shows higher sensitivity to mixture stratification and local equivalence ratio distributions. Wang et al. [17] studied the auto-ignition of naphtha, primary reference fuels (PRF), gasoline, and its surrogate and found out that ignition delay difference is more significant if the ambient temperature was below $750 \mathrm{~K}$ and the difference becomes insignificant when the ambient temperature was above $750 \mathrm{~K}$. Recently, the spray characterization of this GCI RON 77 fuel in comparison with that of certification E10 gasoline fuel was reported. Both the fuels showed very similar liquid and vapor penetration 
under no EGR to high EGR conditions [18, 19]. Further, the fundamental experimental data on fuel spray combustion processes are essential for chemical mechanism development and validating numerical simulations [20]. Some studies have been reported in the literature using optical engine diagnostics on spray combustion process for conventional gasoline direct injection (GDI) engines [21, 22, 23], conventional compression-ignition engines [24, 25, 26] and partially premixed combustion engines [26, 27]. However, according to Baert et al. [28] optical engines are limited in peak pressure and temperature due to design constraints which restricts them to be used for real engine conditions. Thus in this study, the auto-ignition characteristics of GCI RON 77 fuel were investigated using a gasoline multi-hole injector in a constant volume combustion chamber. A wide range of experimental conditions which includes two different ambient pressures (20 and 30 bar), three different ambient temperatures $(800,900,1000 \mathrm{~K})$, three different injection pressures (100, 200, and 450 bar) and three different oxygen concentration (10, 15, $21 \%$ ) representing the in-cylinder conditions of GCI engines were studied.

\section{Experimental set-up}

Experiments were conducted in a pre-burn type constant volume combustion chamber (CVCC) at KAUST Spray Lab. The chamber has six windows out of which two windows are used for optical purposes and one for fixing the injector. The $60 \mathrm{~mm}$ thick quartz window gives a $100 \mathrm{~mm}$ diameter optical access. The CVCC is capable of handling peak pressure up to 150 bar. The schematic of the CVCC system is shown in Fig. 1. Pre-mixed gas preparation, pre-burn initiation, fuel injection activation, and high-speed imaging are 
automated through in-house LabVIEW program such that run to run variations due to the anthropic operation is minimized. Pre-burn gas components were firstly mixed in an accumulator and then pushed by high-pressure nitrogen gas into the CVCC. The gas mixture was ignited by a spark plug such that high pressure and high temperature is formed. Due to heat loss, preburn gas product pressure and temperature will decrease with time. Then the injection is triggered with a carefully selected delay after spark ignition, such that a desired ambient gas pressure and the temperature is achieved. A pressure transducer (Kistler 6041B) coupled with a charge amplifier (Kistler 5018) was utilized to measure the transient chamber pressure during the entire pre-burn combustion, cooling, and spray combustion phase. The output voltage from the charge amplifier was acquired at a frequency of $100 \mathrm{kHz}$ by a DAQ card (National Instrument ${ }^{\mathrm{TM}}$ PCI 6040E).

The fuel injection system consists of a ten-hole solenoid-operated gasoline multi-hole injector and a compressed air-driven liquid pump. The injector used in this study is a Bosch custom made high-pressure injector (HDEV5s) provided by Saudi Aramco for research purposes. The injector hole size is $165 \mu \mathrm{m}$ with a cone angle of $110^{\circ}$. This injector was designed for working at high injection pressures of up to 500 bar. A compressed air-driven liquid pump (Hydraulic International, Inc. 5LSD-410) is used to pressurize the fuel to a maximum pressure of up to 3000 bar. A common rail is connected with the pump and controlled by a LabVIEW ${ }^{\mathrm{TM}} \mathrm{PID}$ program to stabilize the fuel injection pressure. The solenoid injector is controlled using a direct injection driver system (National Instruments ${ }^{\mathrm{TM}}$ DIDS-2003). A dynamic pressure sensor (Kistler 4067E) was fitted to the high-pressure pipe 
connecting the common rail and the injector at $70 \mathrm{~mm}$ from the injector end similar to the ECN community [29]. The dynamic pressure sensor can measure pressure range between 0-3000bar under a working temperature range of $25-180^{\circ} \mathrm{C}$. The high-pressure pipes used are rated at $4000 \mathrm{bar}$.

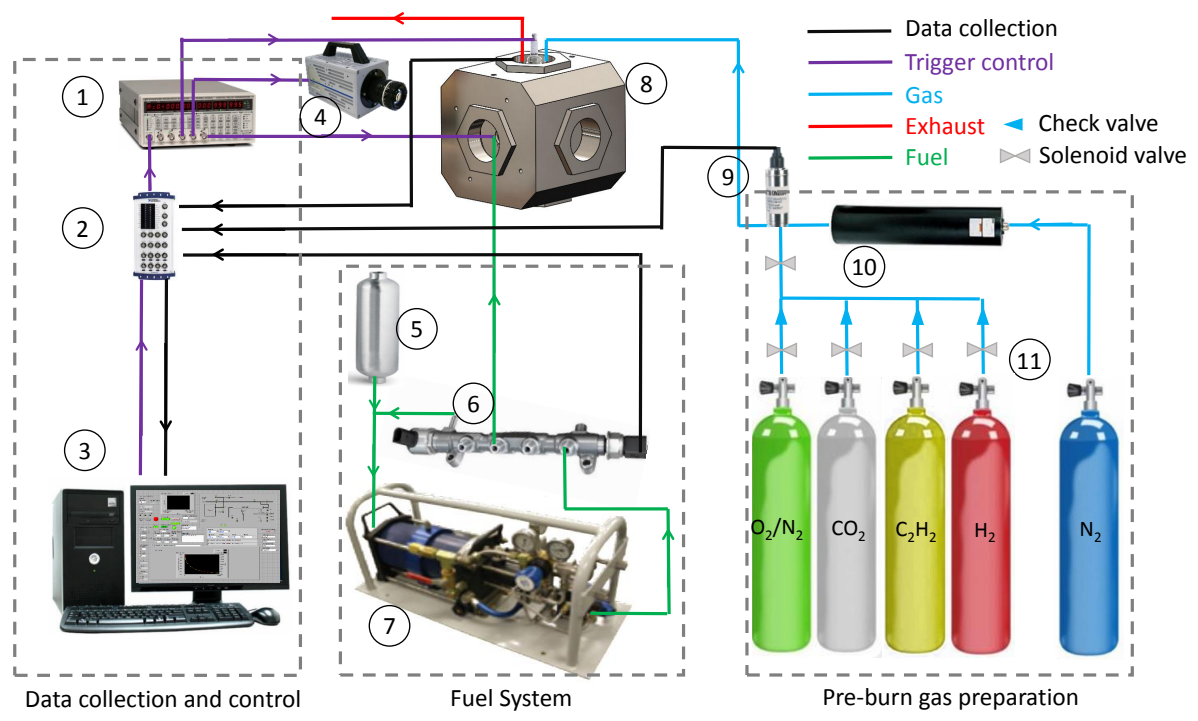

Figure 1: Schematic of pre-burn type Constant Volume Combustion Chamber (CVCC): 1. Delay generator; 2. Data acquisition; 3. PC Software; 4. High speed camera; 5. Fuel tank; 6. Common rail; 7. Air driven liquid pump; 8. CVCC; 9. Gas pressure sensor; 10. Gas accumulator; 11. Gas cylinders.

A high-speed monochrome camera (Photron SA-X2) was used to visualize the combustion event. The camera was employed at $50 \mathrm{kfps}$ to capture the flame evolution with a resolution of $496 \times 384$ pixels. Camera exposure time and the aperture number were selected based on the flame intensity under different ambient conditions. The camera triggering event was synchronized 
with the fuel injection event through a digital pulse generator (Stanford research systems DG535).

\section{Test conditions}

Ignition delay time measurements have been performed at different experimental conditions, which are summarized in table 2. Three different injection pressures of 100, 300, and 450 bar were tested. For each injection pressure, two different ambient pressures (20 and 30 bar), three different ambient temperatures $(800,900$, and $1000 \mathrm{~K})$, and three different oxygen concentrations $(10,15,21 \%)$ were used. An injection duration of $1.75 \mathrm{~ms}$ has been used to ensure fully developed spray. The injection rate measurements were performed using a spray momentum flux method. Details of the measurement principle can be found in [30]. Fig. 2 shows the injection rate profile for three different injection pressures used in this study. The total mass of fuel injected at 100,300, and 450 bar injection pressures was 25, 42.5, and 50 $\mathrm{mg}$, respectively. The experiments were repeated three times for each case. Then the data from the three runs were averaged and reported to account for the uncertainties.

\section{Definition}

The ignition delay time was quantified from the heat release rates calculated based on the pressure measurements during the spray combustion events, as shown in Fig. 3. 


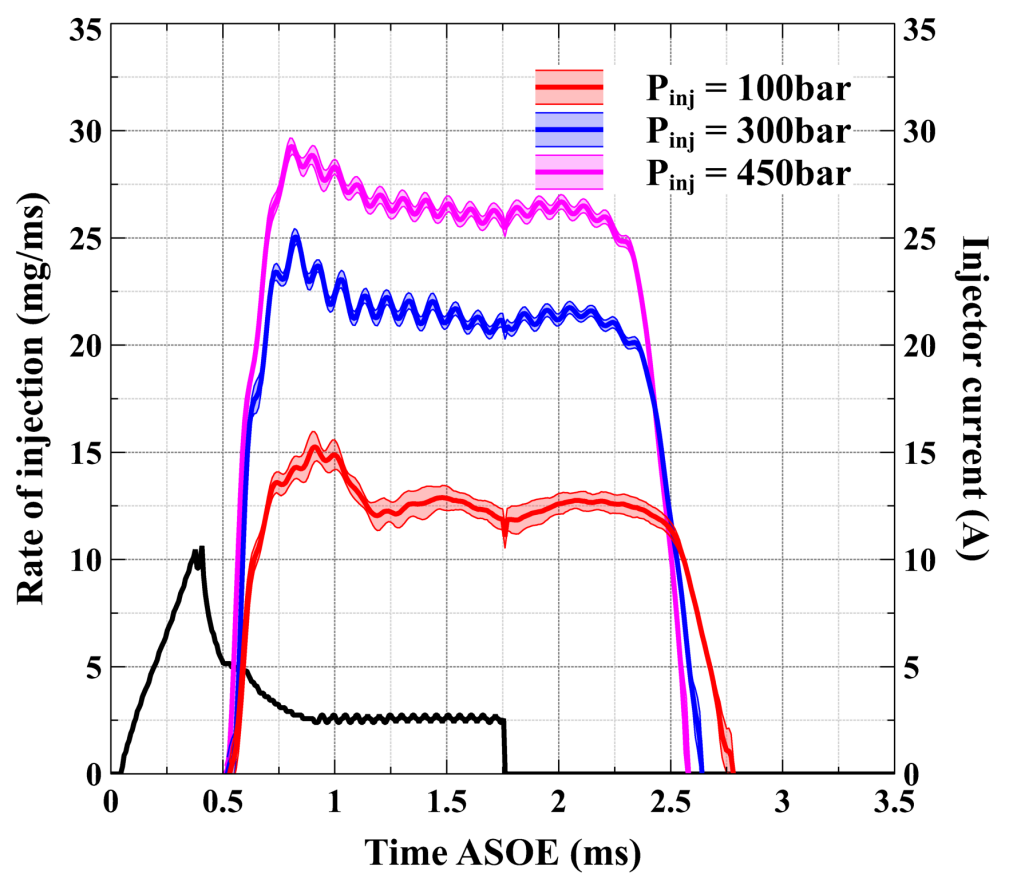

Figure 2: Injection rate profiles along with injector current profile for different injection pressures used
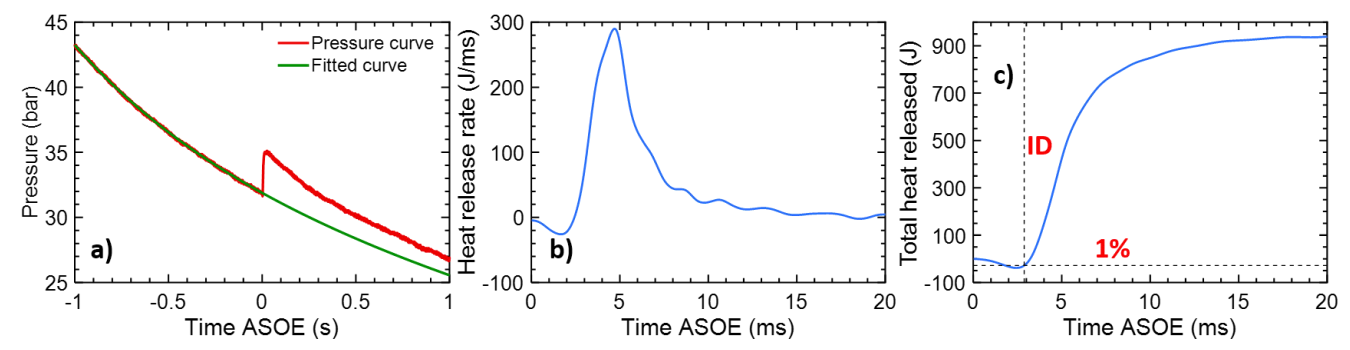

Figure 3: Ignition delay quantification from pressure measurement data a) Raw and fitted pressure data b) Heat release rate c) Accumulated heat release 
Table 2: Test conditions

\begin{tabular}{|c|c|}
\hline Ambient pressure (bar) & 20 and 30 \\
\hline $\begin{array}{c}\text { Ambient temperature } \\
(\mathrm{K})\end{array}$ & 800,900, and 1000 \\
\hline Injection pressure (bar) & 100,300, and 450 \\
\hline $\begin{array}{c}\text { Oxygen concentration } \\
(\%)\end{array}$ & $10,15,21$ \\
\hline
\end{tabular}

decay curve by subtracting an exponentially fitted pressure curve from the original signal. Then the heat release rate is calculated by the formula given in Eq. 1.

$$
\frac{d Q}{d t}=\frac{1}{\gamma-1} V \frac{d P}{d t}
$$

where $Q$ is the heat release in Joule $(J), t$ is the time in second $(s), V$ is the volume in $\left(\mathrm{m}^{3}\right), P$ is the pressure in Pascal $(P a)$, and $\gamma$ is the ratio of the specific heats and in this study $\gamma$ value was taken to be 1.4.

The accumulated heat release is obtained by numerical integration of the heat release rate. In this study, the ignition delay obtained from pressure measurement is defined as the time after start of excitation (ASOE) of the injector until $1 \%$ of the accumulated heat release has occurred [31].

\section{Results and discussion}

Fig. 4 shows the ignition delay time at different a) injection pressure, b) ambient temperature, c) ambient pressure, and d) oxygen concentrations. The ignition delay time spanned from $75 \mu \mathrm{s}$ to $4.5 \mathrm{~ms}$. In some cases, the 
reported ignition delay times occur later than the hydraulic end of injection $(2.78,2.64$, and $2.57 \mathrm{~ms}$ for 100,300 , and 450 bar injection pressures respectively) (refer Fig. 2). This shows that the combustion ranges from conventional diffusion combustion to partially premixed combustion mode.
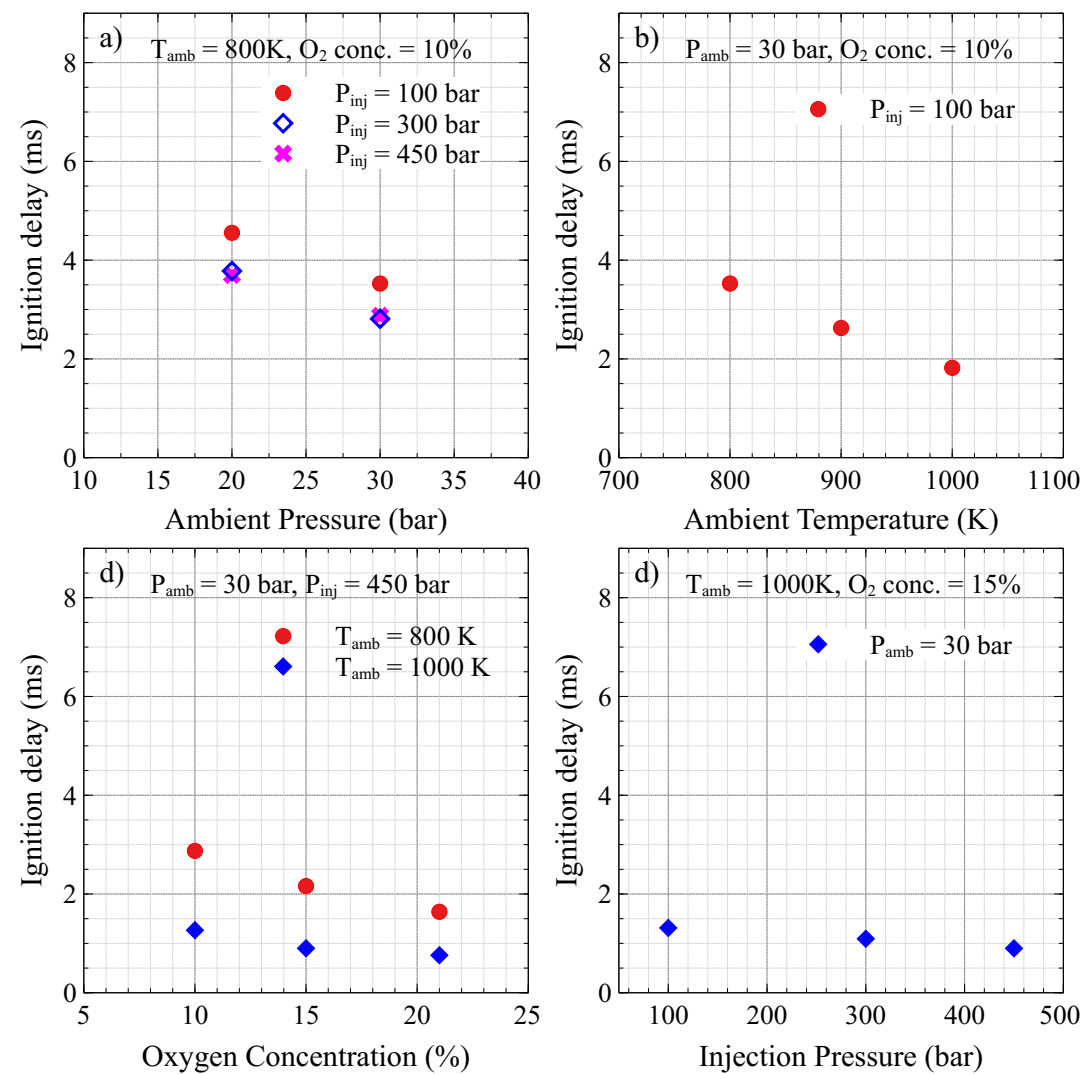

Figure 4: Ignition delay times for GCI RON 77 fuel at different a) ambient pressures, b) ambient temperatures, c) oxygen concentrations and d) injection pressures

It can be seen from Fig. 4a, the ignition delay shows an inverse depen- 
from shock tube and rapid compression machines [13]. It can be noted that the ignition delay at ambient pressure of 30 bar and injection pressures of 300 and $450 \mathrm{bar}$ is $2.813 \mathrm{~ms}$; this shows that the combustion starts immediately after the end of injection (2.64 and $2.57 \mathrm{~ms}$ ). For lower injection pressure of 100 bar at ambient pressure of 30 bar and all injection pressures at ambient pressure of 20 bar, the ignition delay is longer than $3.5 \mathrm{~ms}$, which is later than their respective end of injections. Therefore, partially-premixed combustion is expected, and the mixture stratification is dependent on the ambient pressures.

The ignition delay dependence on ambient temperature is shown in Fig. 4b. The ignition delay at 800,900 , and $1000 \mathrm{~K}$ at ambient pressure of 30 bar, the oxygen concentration of $10 \%$, and an injection pressure of 100 bar are reported as 3.526, 2.626, and $1.82 \mathrm{~ms}$ respectively. The end of injection for 100 bar injection pressure is $2.78 \mathrm{~ms}$. This shows that as the ambient temperature is reduced, the combustion mode transits from spray diffusion to partially-premixed combustion. Fig. 5 shows the heat release rate and accumulated heat release for the different ambient temperatures of 800,900 , and $1000 \mathrm{~K}$ at ambient pressure of 30 bar and oxygen concentration of $10 \%$ for injection pressure of 100 bar. As the ambient temperature is decreased, the accumulated heat release increases. This shows that the partially-premixed combustion mode is more efficient than the spray diffusion mode of combustion. A comparison of auto-ignition flame images is shown in Fig. 6 at different ambient temperatures under ambient pressure of 30 bar, an injection pressure of 100 bar, and oxygen concentration of $10 \%$. It can be seen from the images that at ambient temperatures of $1000 \mathrm{~K}$ and $900 \mathrm{~K}$, combustion is 


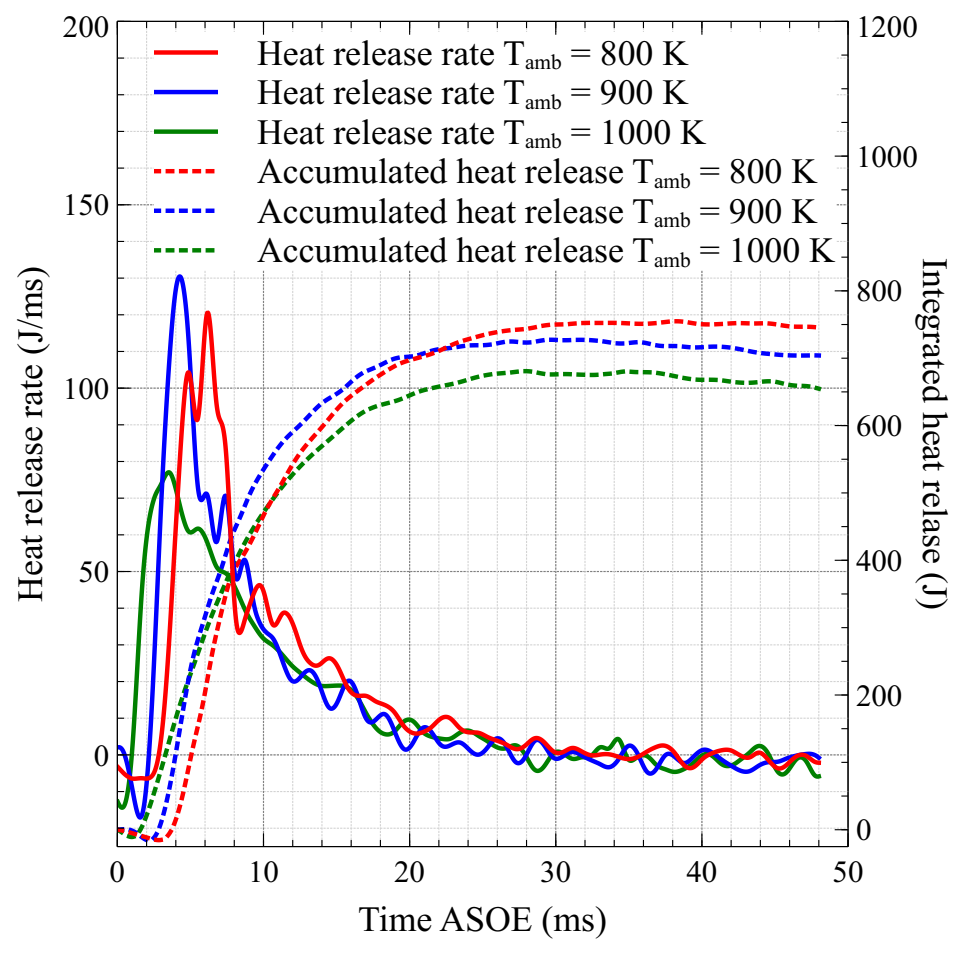

Figure 5: Comparison of heat release rate and accumulated heat release for two different auto-ignition images of GCI RON 77 fuel at different ambient temperatures under ambient pressure of 30 bar, the injection pressure of 100 bar and Oxygen concentration of $10 \%$

predominantly characterized by high-intensity luminous flames due to spray diffusion combustion mode, and at $800 \mathrm{~K}$ it is described by low-temperature partially-premixed combustion. Further, high luminosity flames with higher soot formation results in more heat loss due to thermal radiation, which contributes to the lower accumulated heat release at the end of combustion as seen in Fig.5 for ambient temperatures of $900 \mathrm{~K}$ and $1000 \mathrm{~K}$ compared to that of $800 \mathrm{~K}$. 


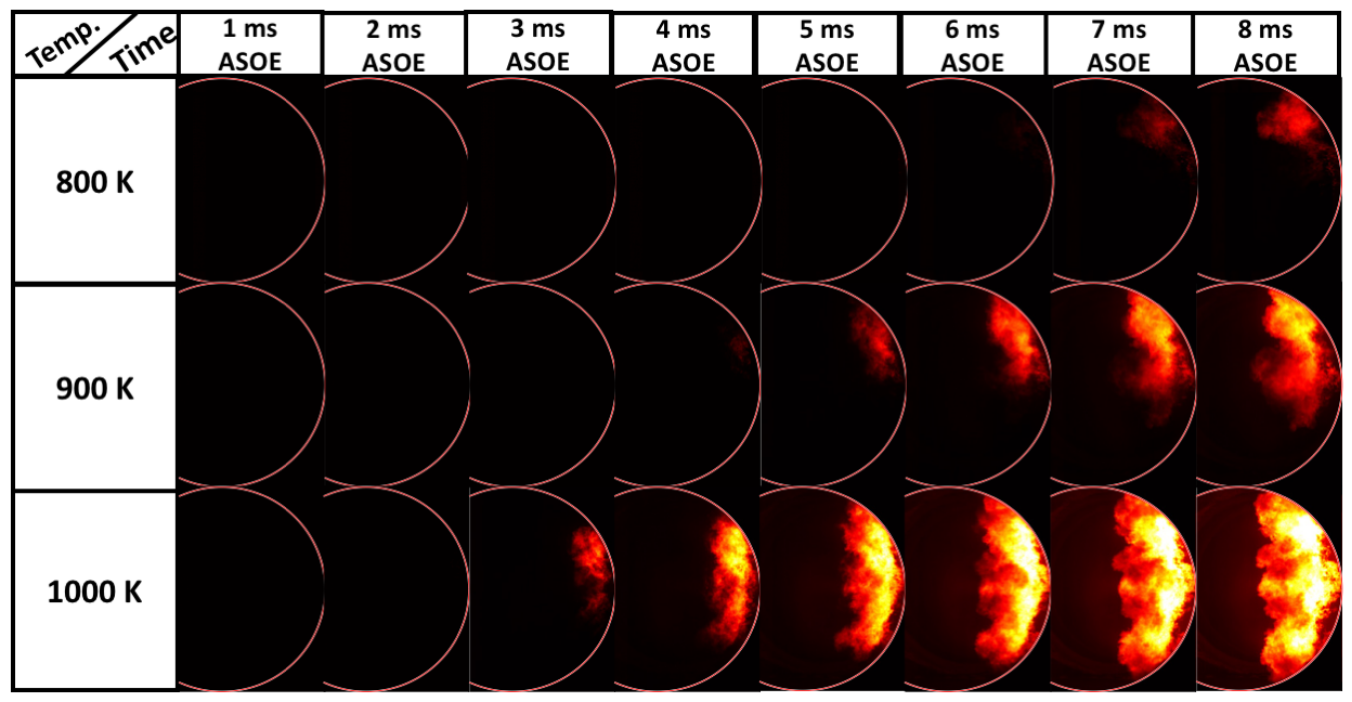

Figure 6: Comparison of auto-ignition images of GCI RON 77 fuel at different ambient temperatures under ambient pressure of 30 bar, the injection pressure of 100 bar and Oxygen concentration of $10 \%$. 
Fig. 4c shows that ignition delay for different oxygen concentrations at ambient temperatures of 800 and $1000 \mathrm{~K}$, the ambient pressure of $30 \mathrm{bar}$, and an injection pressure of 450 bar. It can be seen that the ignition delay decreases as the ambient oxygen concentration increases. It should be noted that for higher injection pressure of 450 bar, the combustion is predominantly governed by spray diffusion since the ignition delay is mostly earlier than the end of injections. The level of spray diffusion combustion mode increases as the oxygen concentration increases. A comparison of flame images is shown in Fig. 7 for different oxygen concentrations at ambient pressure of 30 bar, the ambient temperature of $1000 \mathrm{k}$, and an injection pressure of $450 \mathrm{bar}$.

Fig. 4d shows the ignition delay dependence on the injection pressure. The ignition delays are reported for different injection pressures at ambient pressure of $30 \mathrm{bar}$, ambient temperature of $1000 \mathrm{~K}$, and oxygen concentration of $15 \%$. It is seen that the ignition delay changes very little with the increase in injection pressure, and it is interesting to note that the ignition delay for injection pressures of 300 and 450 bar is almost the same. This behavior shows that the chemical delay compensates for the difference in the physical delay due to variation in the local equivalence ratio. Fig. 8 shows the flame images comparison for different injection pressures under an ambient temperature of $1000 \mathrm{~K}$, the ambient pressure of $30 \mathrm{bar}$, and oxygen concentration of $15 \%$. It can be seen that the combustion is predominantly dominated by spray diffusion mode from high-intensity luminous flame images as the ignition starts well before the end of injection. 


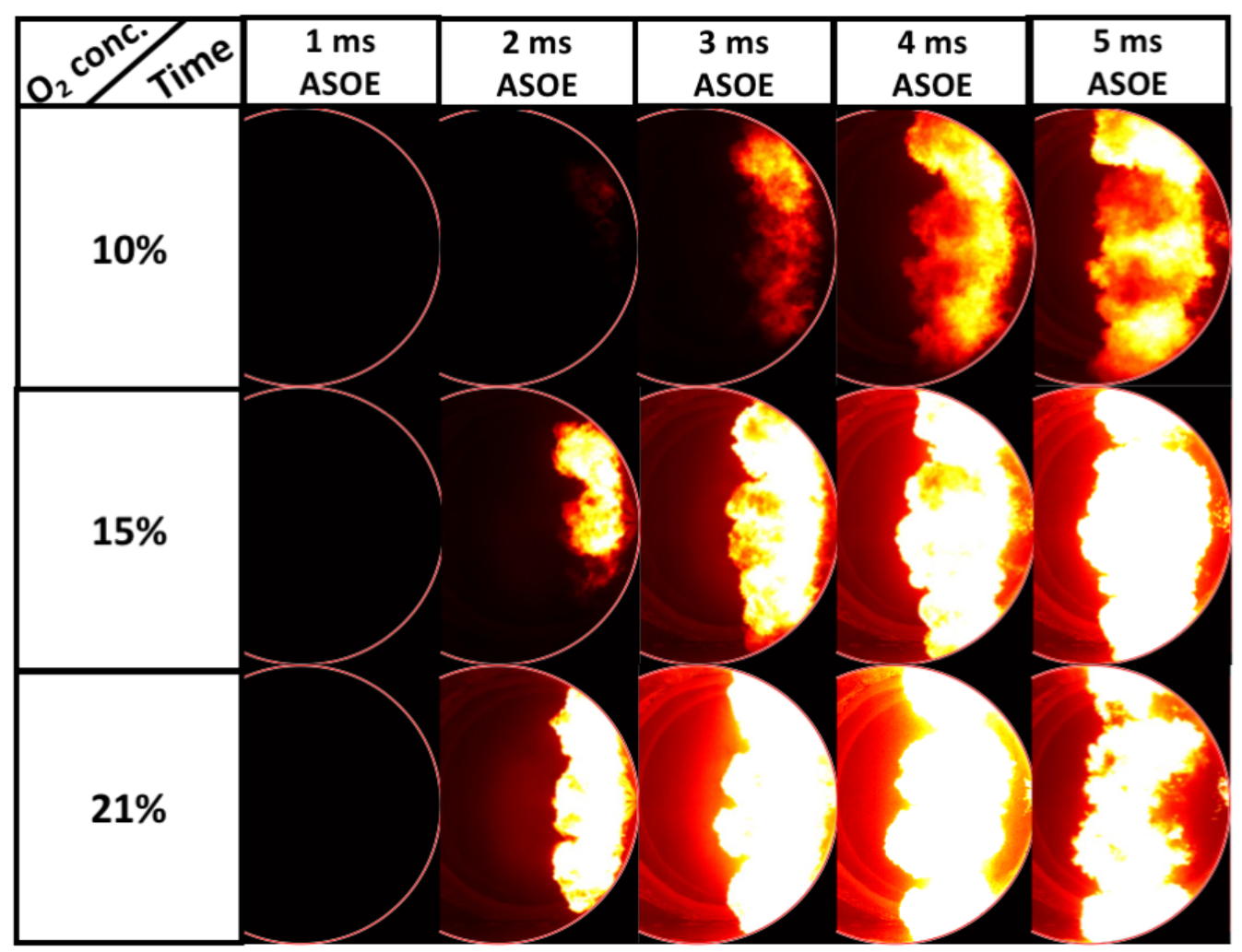

Figure 7: Comparison of auto-ignition images of GCI RON 77 fuel at different Oxygen concentrations under ambient pressure of 30 bar, ambient temperature of $1000 \mathrm{~K}$ and injection pressure of 450 bar. 


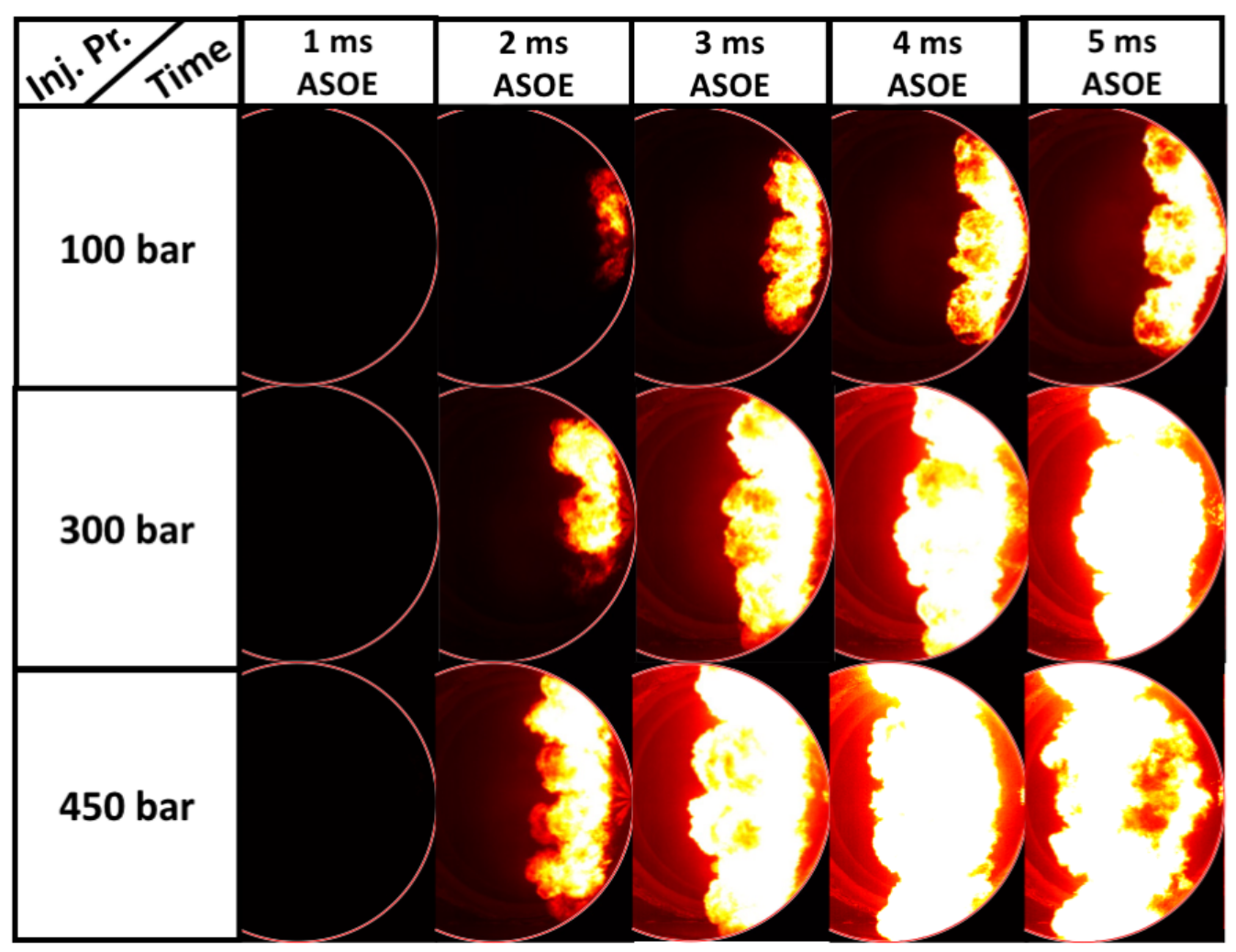

Figure 8: Comparison of auto-ignition images of GCI RON 77 fuel at different injection pressures under ambient pressure of 30 bar, ambient temperature of $1000 \mathrm{~K}$ and Oxygen concentration of $15 \%$.

\section{Conclusions}

This work investigates the auto-ignition of sprays of high-reactivity gasoline fuel (GCI RON 77) using a multi-hole high-pressure gasoline injector under different operating conditions. Different combustion modes were observed.

- It was found that the auto-ignition was observed with noticeable igni- 
tion delay under all conditions tested.

- At high injection pressure of 450 bar and high ambient gas pressure of 30 bar irrespective of oxygen concentration and ambient gas temperature, the ignition delays are shorter and exhibits diffusion mode of combustion.

- Further, at a high ambient gas temperature of $1000 \mathrm{~K}$ and high ambient gas pressure of 30 bar, irrespective of oxygen concentration and injection pressure, the ignition delays are short and exhibits diffusion combustion

- At very relevant GCI engine operating conditions of a low ambient gas temperature of $800 \mathrm{~K}$ and low oxygen percentage of 10\% (high EGR scenario), irrespective of other parameters, the ignition delays are longer and exhibits partially-premixed combustion mode.

\section{Acknowledgments}

This work was sponsored by Saudi Aramco under the FUELCOM II program and by King Abdullah University of Science and Technology.

\section{References}

[1] Y. Zhang, P. Kumar, M. Traver, D. Cleary, Conventional and low temperature combustion using naphtha fuels in a multi-cylinder heavy-duty diesel engine, SAE Int J Engines 9 (2016) 1021-1035. 
[2] J. Chang, Y. Viollet, A. Amer, G. Kalghatgi, Fuel economy potential of partially premixed compression ignition (PPCI) combustion with naphtha fuel, Technical Report, SAE Tech Pap 2013-01-2701, 2013.

[3] G. Kalghatgi, L. Hildingsson, A. Harrison, B. Johansson, Autoignition quality of gasoline fuels in partially premixed combustion in diesel engines, Proc Combust Inst 33 (2011) 3015 - 3021.

[4] M. Sellnau, M. Foster, K. Hoyer, W. Moore, J. Sinnamon, H. Husted, Development of a gasoline direct injection compression ignition (gdci) engine, SAE Int J Engines 7 (2014) 835-851.

[5] A. M. Ickes, S. V. Bohac, D. N. Assanis, Effect of fuel cetane number on a premixed diesel combustion mode, Int J Engine Res 10 (2009) 251-263.

[6] D. Han, A. M. Ickes, S. V. Bohac, Z. Huang, D. N. Assanis, Premixed low-temperature combustion of blends of diesel and gasoline in a high speed compression ignition engine, Proc Combust Inst 33 (2011) 3039 $-3046$.

[7] G. T. Kalghatgi, L. Hildingsson, A. J. Harrison, B. Johansson, Surrogate fuels for premixed combustion in compression ignition engines, Int $\mathrm{J}$ Engine Res 12 (2011) 452-465.

[8] J. Badra, Y. Viollet, A. Elwardany, H. G. Im, J. Chang, Physical and chemical effects of low octane gasoline fuels on compression ignition combustion, Appl Energy 183 (2016) 1197 - 1208. 
[9] J. Chang, G. Kalghatgi, A. Amer, P. Adomeit, H. Rohs, B. Heuser, Vehicle demonstration of naphtha fuel achieving both high efficiency and drivability with euro6 engine-out nox emission, SAE Int J Engines 6 (2013) 101-119.

[10] Y. Zhang, A. Voice, T. Tzanetakis, M. Traver, D. Cleary, An evaluation of combustion and emissions performance with low cetane naphtha fuels in a multicylinder heavy-duty diesel engine, J Eng Gas Turb Power 138 (2016) 102805.

[11] C. P. Kolodziej, M. Sellnau, K. Cho, D. Cleary, Operation of a gasoline direct injection compression ignition engine on naphtha and e10 gasoline fuels, SAE Int J Engines 9 (2016) 979-1001.

[12] C. Jiang, G. Huang, G. Liu, Y. Qian, X. Lu, Optimizing gasoline compression ignition engine performance and emissions: Combined effects of exhaust gas recirculation and fuel octane number, Appl Therm Eng 153 (2019) 669-677.

[13] M. AlAbbad, J. Badra, K. Djebbi, A. Farooq, Ignition delay measurements of a low-octane gasoline blend, designed for gasoline compression ignition (gci) engines, Proc Combust Inst (2018).

[14] B. Mohan, W. Yang, S. kiang Chou, Fuel injection strategies for performance improvement and emissions reduction in compression ignition engines - a review, Renew Sust Energ Rev 28 (2013) 664 - 676.

[15] R. Vallinayagam, S. Vedharaj, Y. An, A. Dawood, M. I. Najafabadi, B. Somers, B. Johansson, Combustion stratification for naphtha from 
CI combustion to PPC, Technical Report, SAE Tech Pap 2017-01-0745, 2017.

[16] H. Goyal, S. Kook, Ignition process of gasoline compression ignition (gci) combustion in a small-bore optical engine, Fuel 256 (2019) 115844.

[17] L. Wang, Z. Wu, A. Ahmed, J. A. Badra, S. M. Sarathy, W. L. Roberts, T. Fang, Auto-ignition of direct injection spray of light naphtha, primary reference fuels, gasoline and gasoline surrogate, Energy 170 (2019) 375390.

[18] J. Du, B. Mohan, J. Sim, T. Fang, W. L. Roberts, Macroscopic nonreacting spray characterization of gasoline compression ignition fuels in a constant volume chamber, Fuel 255 (2019) 115818.

[19] J. Du, B. Mohan, J. Sim, T. Fang, W. L. Roberts, Experimental and analytical study on liquid and vapor penetration of high-reactivity gasoline using a high-pressure gasoline multi-hole injector, Appl Therm Eng 163 (2019) 114187.

[20] R. Novella, A. García, J. Pastor, V. Domenech, The role of detailed chemical kinetics on cfd diesel spray ignition and combustion modelling, Math Comp Model Dyn 54 (2011) 1706 - 1719.

[21] P. Sementa, B. M. Vaglieco, F. Catapano, Thermodynamic and optical characterizations of a high performance gdi engine operating in homogeneous and stratified charge mixture conditions fueled with gasoline and bio-ethanol, Fuel 96 (2012) 204-219. 
[22] P. Sementa, B. M. Vaglieco, F. Catapano, Non-intrusive investigation in a small gdi optical engine fuelled with gasoline and ethanol, SAE Int J Engines 4 (2011) 50-66.

[23] B. G. Moxey, A. Cairns, H. Zhao, A comparison of butanol and ethanol flame development in an optical spark ignition engine, Fuel 170 (2016) $27-38$.

[24] H. Zhao, N. Ladommatos, Optical diagnostics for soot and temperature measurement in diesel engines, Prog Energ Combust 24 (1998) 221-255.

[25] T. Xuan, J. V. Pastor, J. M. García-Oliver, A. García, Z. He, Q. Wang, M. Reyes, In-flame soot quantification of diesel sprays under sooting/non-sooting critical conditions in an optical engine, Appl Therm Eng 149 (2019) 1-10.

[26] Y. An, R. Vallinayagam, S. Vedharaj, J.-B. Masurier, A. Dawood, M. I. Najafabadi, B. Somers, B. Johansson, Analysis of transition from HCCI to CI via PPC with low octane gasoline fuels using optical diagnostics and soot particle analysis, Technical Report, SAE Tech Pap 2017-01$2403,2017$.

[27] H. Shi, Y. An, B. Johansson, Study of Fuel Octane Sensitivity Effects on Gasoline Partially Premixed Combustion Using Optical Diagnostics, Technical Report, SAE Tech Pap 2019-24-0025, 2019.

[28] R. S. Baert, P. J. Frijters, B. Somers, C. C. Luijten, W. de Boer, Design and operation of a high pressure, high temperature cell for HD diesel 
spray diagnostics: guidelines and results, Technical Report, SAE Tech Pap 2009-01-0649, 2009.

[29] L. M. Pickett, C. L. Genzale, G. Bruneaux, L.-M. Malbec, L. Hermant, C. Christiansen, J. Schramm, Comparison of diesel spray combustion in different high-temperature, high-pressure facilities, SAE Int J Engines 3 (2010) 156-181.

[30] B. Mohan, J. Du, J. Sim, W. L. Roberts, Hydraulic characterization of high-pressure gasoline multi-hole injector, Flow Meas Instrum 64 (2018) $133-141$.

[31] M. Tang, J. Zhang, T. Menucci, H. Schmidt, S. Lee, J. Naber, T. Tzanetakis, Experimental spray ignition and soot forming characteristics of high reactivity gasoline and diesel fuel in a heavy-duty single-hole injector, in: Proceedings 10th US National Combustion Meeting-Eastern States Section of the Combustion Institute, College Park, MD, 2017. 